\title{
Claims of Efficiency
}

Efficiency is a question of relativity. If outputs are able to be increased at the same, or preferably lower, costs then the level of efficiency is increased. If $\mathrm{X}$ product can solve the same, or more, problems than $\mathrm{Y}$ product and it costs less to produce and maintain $\mathrm{X}$, then $\mathrm{X}$ is said to be more efficient. The question of efficiency with homeschooling follows the claims that homeschooling outperforms public schools. This claim must be understood and accepted first before claims of efficiency can be made. And, as explicated in the previous chapter, claims of outcomes of homeschooling relative to public schools are tenuous, at best, and misleading at worst. Yet, for a moment, we will take up the assumption pushed by homeschooling advocates that the outcomes of homeschooling compared to public schools is an apples to apples comparison and, thus, evaluations of relative costs (and therefore efficiency) can be considered.

According to the National Center for Education Statistics, the total expenditure for students in the United States during the $2015^{-2016}$ school year was $\$ 706$ billion which equated to $\$ 13,847$ per student $(\$ 12,330$ for educational expenses such as teacher salary, employee benefits, supplies, etc. and $\$ 1,155$ for capital outlays such as buildings and infrastructure) (NCES, n.d.). The bulk of public school expenditures go to cover the salaries of teachers, principals, administrators, and other support staff. Yet, it is important to keep in mind that this is a raw average as the actual per-student expenditure varies dramatically across states and even by district. In 2016, Utah spent only $\$ 6,953$ per student while New York spent \$22,366 with a median expense of \$11,39o (Governing, n.d.). The variation in spending per student is based largely on cost of living differences but can also reflect political attitudes towards governmental spending. Comparatively, homeschooling advocates suggest that it only costs about $\$ 50$ o to educate a child at home annually (Bentley, n.d.-a).

The HSLDA provides a detailed breakdown of the projected costs of homeschooling noting that curriculum is the largest expense but can vary depending on thrift. Costs associated with curriculum can be offset by taking advantage of local libraries and YouTube videos. Combining back-of-the-napkin calculations for a myriad of expenses including curriculum, professional memberships (one with HSLDA, of course), annual homeschooling convention, school supplies, etc. the cost to homeschool three children would be $\$ 2,275$ or $\$ 75^{8}$ per child (Bentley, n.d.-b). However, when considering the costs of educating a child, the HSLDA provides the following caveat: "last, but certainly not least, 
pray about the needs you have for your homeschool and ask God to provide these things" (Bentley, n.d.-b). To the task of determining and comparing efficiencies between homeschooling and public schools, it is decidedly difficult to quantify the value of those resources provided by God for comparative purposes.

Within the broader libertarian and neoliberal critique of government-run traditional public schools is that government, itself, is terribly inefficient at running, overseeing, and providing services generally speaking. The logic, as it were, is that the additional levels of bureaucracy associated with governments that are in place to ensure accountability and oversight create unnecessary burdens on the delivery of goods and services and, thus, add unnecessary costs. Rather than operating under such a system, pro-market ideologies assert that free-markets and deregulation (both understood as being connected and equally separate concepts and practices) will turn over the services long managed by governments to the invisible hand of the free market and, as a result, will force such services to adapt to the efficiencies that are believed to come with market competition as opposed to government monopolies.

Beginning heavily in the 198 os, the education policy landscape has seen increased efforts to deregulate schools and teacher preparation by turning them over to free market oriented reforms. The push to deregulate schools has been a result of not only this generic political and economic ideology that market competition is always preferred over government-run services but it has been bolstered by the continued myth of the 'failed public school' and the 'bad teacher.' It is important, now, to point out that the critique of efforts to reform and privatize education that follows should not be understood or interpreted as an endorsement of the status quo or the history of public schools. Indeed, public schools have been wrought with inequalities and injustices - primarily centering around issues of race and class - and this is a troubled history that warrants critique and reform. That said, the inequalities within public schools have long been a mirror of the inequalities within the larger society and while schools have long been responsible for the reproduction of such inequalities (Bowles \& Gintis, 1976), they are not, singularly, responsible for the creation of such inequity. Ultimately, because schools have long been understood as providing an equal and level playing field within the guise of meritocracy (Brewer \& Myers, 2015), the persistence of socioeconomic inequalities has been understood as: (1) a failure of the public school system to ameliorate systemic poverty; and/or, (2) a failure of students and their communities to take advantage of those perceived equal opportunities. Indeed, many homeschooling parents simply want to isolate their children away from those students and communities that are understood through deficit ideologies (Ahlquist, Gorski, 
\& Montano, 2011; Gorski, 2011). Further, teachers have increasingly become the scapegoat for these perceived failures and, as a result, have become targets of unfair critique (Goldstein, 2014; Kumashiro, 2012). While the myth of the failed school can be traced back to the launch of Sputnik (and the perceived failure of U.S. public schools to produce students capable of competing with the Soviet Union), there has been a heightened sense of critique stemming from the Regan administration's release of A Nation at Risk (ANAR) and his administration's embrace of the free-market neoliberal ideologies espoused by Milton Friedman (deMarrais, Brewer, Atkinson, Herron, \& Lewis, 2019; Harvey, 2005).

Policy efforts that purport to attend to these perceived failures have manifested by way of charter schools (Lubienski \& Weitzel, 2010), school vouchers (Lubienski \& Brewer, 2016), alternative teacher certification programs (Brewer, 2014; Brewer \& deMarrais, 2015; Brewer, Kretchmar, Sondel, Ishmael, \& Manfra, 2016), and a resurgence of homeschooling (Brewer \& Lubienski, 2017; Lubienski \& Brewer, 2014; Lubienski, Puckett, \& Brewer, 2013).

The NHERI claims that homeschooling families save taxpayers over \$27 billion per year because taxpayers spend, on average, $\$ 11,73^{2}$ per student per year and the average expenditure to homeschool a student is $\$ 6$ oo per student annually (Ray, 2019). On the surface it would appear that Ray is correct that the homeschooling of 2.3 million students at a reduced cost of $\$ 11,132$ per year $(\$ 11,732$ - \$6oo) would equate to savings of $\$ 25,603,600,000$ annually.

However, these figures are wildly misleading on the face of it. The majority of households that homeschool are a two-parent household where only one parent is in the labor force. As such, the majority of homeschooling families forgo a second source of income to stay at home and homeschool.

A survey conducted Brian Ray in 2009 noted that the median income for families who homeschool was $\$ 74,049$ in 2006 dollars or $\$ 78,49$ o in 2008 dollars, controlling for inflation (Ray, 2009b). Updating those numbers to 2019 suggests that the estimation of comparative dollars would be $\$ 94,083$ (U.S. Inflation Calculator, n.d.). Estimates of the national median of household income in the United States during 2019 hover around \$63, ooo (Seeking Alpha, 2019). Thus, the typical homeschooling family makes nearly 50\% more than the typical household in the United States. And this is a striking and notable reality considering that the majority of homeschooling families have willingly forgone a parent's salary so that they can remain at home to teach their children. And while this is certainly not the case in all iterations of homeschooling, a single-income that is $50 \%$ larger than the national median household income positions the earner themselves at the top of the individual-earning bracket. The FRED data suggests that the real median personal income in 2016 was $\$ 31$, o99 (FRED, n.d.) or \$33,189 adjusted to 2019 dollars (U.S. Inflation 
Calculator, n.d.). With this in mind, it becomes clearer that the claims made by the NHERI and other homeschooling advocacy organizations and individuals that the cost of homeschooling is significantly less than the collective cost of sending a child to a traditional public school fall flat on their face. Claiming that it only costs $\$ 6$ oo per year to homeschool a child requires some convenient assumptions and omissions by homeschooling advocates: (1) That there would be enough household income to offset the loss of an income stream from the person staying home to teach - traditionally, but not always, the mother; (2) That there are additional costs associated with 2+ people staying at home for the majority of the day (e.g., heating and air conditioning, electricity, etc.) when compared to a house that might normally be vacant during the day; (3) shifts the funding accountability of what is normally understood as a public good to the individual; (4) that the suggested weekly outings and fieldtrips would equate to increased - but not reported - costs related to transportation and entry fees (e.g., museum admission); and, (4) fails to recognize that the public is still providing some funding and services towards a child's education through the collective funding of public libraries, roads, facilities and materials for extracurricular activities organized by a traditional public school and made available to homeschoolers, etc.

So, not only does the median homeschooling household make upwards of $50 \%$ more than the median household in the United States, if the household income of a homeschooling family is the result of a single-income (again, assuming that one parent is not working to stay at home to conduct homeschooling), then it is suggestive that the typical single-income of a homeschooling household is three times the national median. Said another way, a single-income of a homeschooling family may bring in the equivalent of what three other Americans make in their jobs $(\$ 33$, ooo compared to $\$ 94,000)$. Comparisons of the academic outcomes of homeschooled students to their traditional public school counterparts are, therefore, a comparison of apples and oranges. Not only does this apples and oranges comparison grossly misstate the costs associated with homeschooling which are nearly three times the cost, but it hides some of the socioeconomic privileges that are borne out by growing up in a family with considerable relative wealth. We have known for more than half a century that one of the strongest predictors of academic outcomes is a family's socioeconomic status and the resources such wealth can bring - or a lack of resources in the case of relative poverty (Bowles \& Gintis, 1976; Brewer \& Myers, 2015; Carter \& Welner, 2013; Coleman, 199o; Coleman et al., 1966; Ennis, 1976; Jencks \& Phillips, 1998; Jencks et al., 1972; Ladson-Billings, 2006; Rothstein, 2004; Wilkinson \& Pickett, 2010). 
TABLE 6.1 Income and educational expenses (in 2019 dollars)

National median Homeschooling family

\begin{tabular}{llc}
\hline Personal income (singular income) & $\$ 33,000$ & $\$ 94,000^{\mathrm{a}}$ \\
Household income $(1+$ incomes) & $\$ 63,000$ & $\$ 94,000$ \\
Reported cost of education & $\$ 11,13^{2}$ & $\$ 600$ \\
Estimated actual cost of education & $\$ 12,25^{\mathrm{b}}$ & $\$ 33,600^{\mathrm{c}}$ \\
\hline
\end{tabular}

a Assumes a single-income household.

b Includes the estimated $\$ 519$ in back-to-school spending (Jones, 2019).

c Estimation combines NHERI homeschooling costs with the median personal income as a

forgone income.

These claims of efficiency are similar to the claims made by pro-voucher advocacy organizations and individuals who have suggested that the use of vouchers to allow students to use public funds to offset the costs of private school tuition results in a net savings for tax payers. For example, a report by the pro-voucher organization of EdChoice (which was formerly known as the Friedman Foundation named after Milton Friedman), claimed that,

In nearly every school choice program, the dollar value of the voucher or scholarship is less than or equal to the state's formula spending per student. This means states are spending the same amount or less on students in school choice programs than they would have spent on the same students if they had attended public schools, producing a fiscal savings. (Aud, 2007, p. 5)

The problem, here, is that while a voucher (or a homeschool tax credit or something similar) that is less than what the state is spending per student for public school attendance gives the appearance of fiscal savings, it disguises the full and hidden costs. That is, in the case of a voucher to attend a private school that is less than the surface costs of the same student attending a public school, the hidden costs are still present and become the burden of both the individual family and for the community. Because most private schools do not provide transportation, it is entirely the financial burden of individual families to arrange for private transportation to attend the private school of their choice. This, obviously, costs money related to the ownership of reliable private transportation (e.g., the car itself, insurance, maintenance, gas, etc.). So, 
as EdChoice suggests, "If a state spends $\$ 6$,ooo per student in public schools and offers a $\$ 5$, ooo voucher, every student who uses a voucher saves the state $\$ 1,000$ " (Aud, 2007, p. 14). However, the state is, in essence, not saving this full amount (in fact, it increases the cost per student) and the cost burden is shifted to individual families - two realities worth exploring at length.

While EdChoice's surface level math would seem to support claims that school choice mechanisms are efficient because they save the government money, such claims miss the larger picture. While it is true that the removal of a singular student into a homeschooling or private school environment will be one less student utilizing some of the school's resources, the cost of each of those resources understood as a per-student basis goes up. The cost to operate a school bus, air condition a school building, purchase paper towels, etc. generally remain steady despite the total number of students. The total cost to operate a school bus is about the same for 50 students as it is for 10 students. However, the more students that school bus serves, the lower the per-student cost is for the district. Moreover, as school choice mechanisms such as homeschool tax credits or private school vouchers shift money from the hands of the public into private hands, the public school is forced to operate these resources and services not only at a higher per-student cost but with a reduced overall budget as the money changes hands.

Considering the hypothetical math from EdChoice provided above, individual families utilizing a voucher appear to save the state $\$ 1,000$ through their use of a voucher. However, the use of such a voucher dramatically shifts the financial burden of education to the individual family. Not only are they far more likely to have to supplement the cost of private school tuition above the level that a $\$ 5,000$ voucher would cover (thus increasing the total cost of education relative to public schools) but they also have to provide their own transportation and in some cases provide volunteer hours.

Aside from the math surrounding the use of publicly-funded school-choice mechanisms, the larger philosophical question here remains about for whom, and by whom, is the purpose of education. The use of tax-credits for homeschooling or vouchers for private school attendance, shifts a significant portion of the funding burden to the individual family which, understanding money as a proxy for values, situates schooling as a process and an ends exclusively for individual purposes. It is the "I got mine, go get your own" mantra manifested in education.

To put it plainly, claims that homeschooling costs less than the cost of educating a child at a local public school are wholly unfounded and misleading. On the surface, claims related to the cost of educating a child are often presented as $\mathrm{X}$ expenditures related to curriculum costs compared to $\mathrm{Y}$ costs 
associated with the entire cost of educating a child at a public school. What is often presented is a glaring disparity in the associated costs, presenting homeschooling as an option that not only realizes considerable academic success but does so at a fraction of the cost. If homeschooling does, in fact, produce greater academic outcomes than public schools and it is a function of the type of schooling, and it is done considerably cheaper, such a practice is open to the adoption of a commonsensical rhetoric that purports to support homeschooling over public schooling. Of course, considerable questions should be raised when there are claims of, or the appearance of, the type of school (e.g., homeschooling) is the mechanism causing the difference in academic outcomes rather than, say, family socioeconomic status, parental educational attainment, etc. Such nuance and context is rarely included in conversations in the pro-homeschooling movement. For instance, the NHERI has a long history of presenting the costs of homeschooling compared to the cost of public schooling in what appears to be an apples to apples comparison but is decidedly an apples to oranges comparison on deeper examination.

TABLE 6.2 Cost over time

\begin{tabular}{lcc}
\hline & Homeschooling & Public school \\
\hline 1999 & $\$ 546$ & $\$ 5,325$ \\
2009 & $\$ 400-\$ 599$ & $\$ 9,963$ \\
2019 & $\$ 600$ & $\$ 11,732$ \\
\hline
\end{tabular}

SOURCE: ADAPTED FROM RAY (2009A, 2015, 2019)

Note here that the cost associated with educating a child in a local public school has continued to rise over the twenty year period in Table 6.2 whereas the reported costs associated with homeschooling have remained almost entirely flat. The cost associated with educating a child at a state-run public school will, naturally, increase over time as the costs associated with running any enterprise becomes more expensive due to inflation. While teacher salaries have remained disturbingly low relative to their professional counterparts for the past two decades, there have been necessary raises over time. Costs associated with bussing, electricity, food, etc. have all, likewise, increased over time. But, also, in the decades following the passage of the Individuals with Disabilities Education Act (IDEA), more students are being properly diagnosed with learning disabilities and, as a result of the law, being provided with the necessary accommodations that often bring with them a higher financial cost. 
As a society we have committed to providing adequate services for our children who need them and to the varying degree that they need them. This is something to take pride in as a society given that many other countries do not provide these protections and services for all students. That said, the cost per student associated with public education has steadily risen since the passage of IDEA. While anti-public school, pro-privatization, individuals and organizations will claim that slow growth in academic outcomes (which is growth) relative to the faster growing costs is representative of the inefficiency of public education while not acknowledging the impact that IDEA has had on our per-pupil funding. Nevertheless, it should be clear that presenting a rising cost associated with public education while suggesting that the costs associated with homeschooling have remained flat is incredibly deceptive.

On the face of it, homeschooling advocates claim that homeschooled students outperform their public school counterparts for pennies on the dollar, therefore homeschooling represents a more efficient method of education. In fact, the HSLDA has claimed that, "The message is loud and clear. More money does not mean a better education" (Home School Legal Defense Association, 2004). Ray has also claimed that "taxpayers spend nothing on most homeschool students" (Ray, 2015) yet nearly all homeschooling guides, curriculums, and advocates suggest making use of public libraries, public parks, and even the extracurricular options made available by local public schools - thus increasing the actual cost of homeschooling as the funding that makes it possible is omitted from HSLDA calculations.

Ultimately, however, comparisons of homeschooling academic outcomes and those of public schools is not only an apples to oranges comparison (which challenges claims of effectiveness), but when the full financial costs of homeschooling are brought into focus, significant challenges arise to claims of efficiency given the considerable amount of money it costs to homeschool. These increased costs include the forgoing of a salary, increased electric costs, increased heating/air costs, increased transportation costs, etc. that are required to teach a child at home.

\section{References}

Ahlquist, R., Gorski, P. C., \& Montano, T. (Eds.). (2011). Assault on kids: How hyperaccountability, corporatization, deficit ideologies, and Ruby Payne are destroying our schools. Peter Lang Publishing.

Aud, S. L. (2007). Education by the numbers: The fiscal effect of school choice programs, 1990-2006. Friedman Foundation. https://www.edchoice.org/wp-content/ uploads/2015/og/Education-by-the-Numbers-Fiscal-Effect-of-School-ChoicePrograms.pdf 
Bentley, V. (n.d.-a). Homeschooling on a shoestring. Retrieved April 10, 2020, from https://hslda.org/content/earlyyears/Shoestring.asp

Bentley, V. (n.d.-b). What does it cost to homeschool? Retrieved April 10, 2020, from https://hslda.org/content/earlyyears/Costs.asp

Bowles, S., \& Gintis, H. (1976). Schooling in capitalist America. Harper Collins.

Brewer, T. J. (2014). Accelerated burnout: How teach for America's academic impact model and theoretical framework can foster disillusionment among its corps members. Educational Studies, 50(3), 246-263.

Brewer, T.J., \& deMarrais, K. (Eds.). (2015). Teach for America counter-narratives: Alumni speak up and speak out. Peter Lang.

Brewer, T. J., Kretchmar, K., Sondel, B., Ishmael, S., \& Manfra, M. (2016). Teach for America's preferential treatment: School district contracts, hiring decisions, and employment practices. Educational Evaluation and Policy Analysis, 24(15), 1-38.

Brewer, T. J., \& Lubienski, C. (2017). Homeschooling in the United States: Examining the rationales for individualizing education. Pro-Posições, 28(2), 21-38.

Brewer, T. J., \& Myers, P. S. (2015). How neoliberalism subverts equality and perpetuates poverty in our nation's schools. In S. N. Haymes, M. V. d. Haymes, \& R. Miller (Eds.), The Routledge handbook of poverty in the United States (pp. 190-198). Routledge.

Carter, P. L., \& Welner, K. G. (Eds.). (2013). Closing the opportunity gap: What America must do to give every child and even chance. Oxford University Press.

Coleman, J. (1990). Equality and achievement in education. Westview Press.

Coleman, J., Campbell, E. Q., Hobson, C. J., McPartland, J., Mood, A. M., Weinfeld, F. D., \& York, R. L. (1966). Equality of educational opportunity. U.S. Department of Health, Education, and Welfare.

deMarrais, K., Brewer, T. J., Atkinson, J. C., Herron, B., \& Lewis, J. (2019). Philanthropy, hidden strategy, and collective resistance: A primer for concerned educators. Myers Education Press.

Ennis, R. H. (1976). Equality of educational opportunity. Educational Theory, 26(1), 3-18. FRED. (n.d.). Real median personal income in the United States. https://fred.stlouisfed.org/series/MEPAINUSA6 $72 \mathrm{~N}$

Goldstein, D. (2014). The teacher wars: A history of America's most embattled profession. Doubleday.

Gorski, P. C. (2011). Thoughts on authenticating the class discourse in education. In R. Ahlquist, P. C. Gorski, \& T. Montano (Eds.), Assault on kids: How hyper-accountability, corporatization, deficit ideologies, and Ruby Payne are destroying our schools (pp. 152-173). Peter Lang Publishing.

Governing. (n.d.). Education spending per student by state. Retrieved April 10, 2020, from https://www.governing.com/gov-data/education-data/state-educationspending-per-pupil-data.html

Harvey, D. (2005). A brief history of neoliberalism. Oxford University Press. 
Home School Legal Defense Association. (2004). Academic statistics on homeschooling. Home School Legal Defense Association. http://www.hslda.org/docs/nche/ oooo10/200410250.asp

Jencks, C., \& Phillips, M. (Eds.). (1998). The Black-White test score gap. Brookings Institution Press.

Jencks, C., Smith, M., Acland, H., Bane, M. J., Cohen, D., Gintis, H., ... Michelson, S. (1972). Inequality: A reassessment of the effect of family and schooling in America. Basic Books, Inc.

Jones, C. (2019). Don't get sidetracked, carry coupons and focus on price, say back-toschool shoppers. Retrieved August 5, 2019, from https://www.usatoday.com/story/ money/2019/o7/10/back-school-shopping-price-sales-what-mattermost/1659567001/

Kumashiro, K. (2012). Bad teacher! How blaming teachers distorts the bigger picture. Teachers College Press.

Ladson-Billings, G. (2006). From the achievement gap to the education debt: Understanding achievement in U.S. schools. Educational Researcher, 35(7), 3-12.

Linsenbach, S. (2010). The everything guide to homeschooling: Allyou need too create the best curriculum and learning environment for your child. Adams Media.

Lubienski, C., \& Brewer, T. J. (2014). Does home education "work"? Challenging the assumptions behind the home education movement. In P. Rothermel (Ed.), International perspectives on home education: Do we still need schools? (pp. 136-147). Palgrave.

Lubienski, C., \& Brewer, T. J. (2016). An analysis of voucher studies: A closer look at the uses and limitations of 'gold standard' advocacy research. Peabody Journal of Education, 91(4), 455-472.

Lubienski, C., Puckett, T., \& Brewer, T. J. (2013). Does homeschooling "work"? A critique of the empirical claims and advocacy agenda. Peabody Journal of Education, 32(6), 283-295.

Lubienski, C., \& Weitzel, P. (Eds.). (2010). The charter school experiment: Expectations, evidence, and implications. Harvard Education Press.

NCES. (n.d.). Public school expenditures. Retrieved April 10, 2020, from https://nces.ed.gov/programs/coe/indicator_cmb.asp

Ray, B. D. (2009a). Homeschool progress report 2009: Academic achievement and demographics. Home School Legal Defense Association. https://eric.ed.gov/?id=ED535134

Ray, B. D. (2009b). Homeschooling across America: Academic achievement and demographic characteristics. Retrieved August 5, 2019, from https://www.nheri.org/ homeschooling-across-america-academic-achievement-and-demographiccharacteristics/

Ray, B. D. (2015). Research facts on homeschooling. National Home Education Research Institute. http://www.nheri.org/ResearchFacts.pdf 
Ray, B. D. (2019). Research facts on homeschooling. Retrieved August 5, 2019, from https://www.nheri.org/research-facts-on-homeschooling/

Rothstein, R. (2004). Class and schools: Using social, economic, and educational reform to close the Black-White achievement gap. Economic Policy Institute.

Seeking Alpha. (2019). Median household income in January 2019. Retrieved August 5, 2019, from https://seekingalpha.com/article/4244715-median-household-incomejanuary-2019

U.S. Inflation Calculator. (n.d.). Inflation calculator. Retrieved August 5, 2019, from https://www.usinflationcalculator.com

Wilkinson, R., \& Pickett, K. (2010). The spirit level: Why greater equality makes societies stronger. Bloomsbury Press. 